\title{
International free and fair election instruments developed by UN and OSCE
}

\author{
Azer Kasumov \\ Riga Graduate School of Law \\ Riga, Latvia
}

\section{Introduction}

A number of international conventions and human rights standards show that free and fair elections is one of the major part of human rights. These include the International Covenant on Civil and Political Rights, the Convention on the Elimination of All Forms of Discrimination against Women (CEDAW), ${ }^{1}$ Universal Declaration of Human Rights (UDHR), ${ }^{2}$ the International Convention on the Elimination of All Forms of Racial Discrimination (CERD) ${ }^{3}$ and regional instruments of Europe, first Additional Protocol to the European Convention on Human Rights (ECHR). ${ }^{4}$ Besides these, 'the necessary features of elections are further detailed by the Human Rights Committee (HRC) in General Comment $25 \backslash 57$ (1996)'.5

International and local observation is important for the ensuring protection of the election rights of citizens. The history of modern observation starts from 1857 when the representatives from Austrian, Turkish, French, Prussian, British and Russian observed general elections in Moldavia and Wallachia disputed territories. ${ }^{6}$

\section{Instruments developed by the OSCE}

The standards for the free and fair elections are defined in the principles adopted by international conventions and international organizations. The standards deter-

\footnotetext{
${ }^{1}$ Article 7 of CEDAW.

${ }^{2}$ Article 21 of UDHR.

${ }^{3}$ Article 5 of CERD.

${ }^{4}$ Article 3 of First Additional Protocol to the ECHR.

${ }^{5}$ Christina Binder "International Election Observation by the OSCE and the Human Right to Political Participation", (2007), European Public Law, Vol 13, Issue 1, p.136

${ }^{6}$ OSCE ODHIR, A decade of monitoring elections: the people and the practice; Available on; http://www.osce.org/odihr/elections/17165.
} 
mined by the OSCE consist of number of commitments and recommendations. 'Although OSCE commitments are not legally binding, they serve as common standards of reference and are supposed to foster implementation in a similar way as obligatory standards'?

These standards were welcomed in Europe and in post-soviet states. As we know, in the beginning when the OSCE (CSCE until 1991) was established, the main goal of the organization was strengthening security and cooperation in Europe. But, later according to Helsinki Final Act, the OSCE expanded its active-ties to human rights, democracy, and election. From 1990, the function of the OSCE was more related to human rights and elections. The reason was the collapse of USSR and the serious challenges and shortcomings in newly established states about free elections. At the same time, the adoption of Copenhagen document facilitated the OSCE to operate more sustainably in this direction. 1990 Cophenagen Document $^{8}$ adopted in Copenhagen meeting of the Conference on Human Rights Dimension of the CSCE. "At the Copenhagen Meeting the participating States held a review of the implementation of their commitments in the field of the human dimension. They considered that the degree of compliance with the commitments contained in the relevant provisions of the CSCE documents had shown a fundamental improvement since the Paris Meeting. They also expressed the view, however, that further steps are required for the full realization of their commitments relating to the human dimension". 9

This document has set up standards on free and fair election. Since 1990, participating states has been required to comply with the obligations noted in the Copenhagen Document during the elections. For example, OSCE/ODIHR Election Observation Mission Final Report on Azerbaijan Parliamentary Elections says "[such] actions are not conducive to campaigning in a free and fair atmosphere, and voter intimidation limits the ability of voters to freely choose their representatives without fear of retribution, both contrary to paragraph 7.7 of the Copenhagen Document"10 or "the EOM had two main concerns with regard to the language test. First, assessing a candidate.s command of the State language was in breach of Article 25 of the International Covenant of Civil and Political Rights,

\footnotetext{
${ }^{7}$ Christina Binder "International Election Observation by the OSCE and the Human Right to Political Participation", (2007), European Public Law, Vol 13, Issue 1, p.138

${ }^{8}$ Document of the Cophenagen Meeting of the Conference on the Human Rights Dimension of the CSCE, 29 June 1990. Available on: http://www.osce.org/odihr/elections/14304.

${ }^{9} 1990$ Cophenagen Document (29 June 1990). Available on: http://www.osce.org/odihr/elections/14304.

${ }^{10}$ See OSCE/ODIHR Election Observation Mission Final Report on 2010 Parliamentary Elections of Azerbaijan (25 January 2011), page 4. Available on http://www.osce.org/odihr/elections/azerbaijan/75073.
} 
ratified by the Kyrgyz Republic, and Article 5 of the OSCE Copenhagen Document. Language requirement can serve to limit the possibilities for political participation by national minorities". "This document could be considered main election and political participation document of OSCE. Because the Document dealing with all aspects of elections in particular of paragraphs 5, 6 and 7 . Paragraph 6 to refers main elements of elections and paragraph 7 refers to basic requirements of elections. It says that to ensure that the will of the people serves as the basis of the authority of government, the participating States will; hold free elections at reasonable intervals (7.1), guarantee universal and equal suffrage (7.3), ensure that election campaigning is conducted in a free and fair atmosphere (7.7).

The reason of effectiveness of those obligations is the observation of election processes in OSCE participating States. But what is the election observation? According with International Institute for Democratic and Electoral Assistance (IDEA), 'election observation purposeful gathering of information regarding an electoral process, and making informed judgements on the conduct of such a process on the basis of the information collected, by persons who are not authorized to intervene in the process'. ${ }^{12}$ It is clear from the definition that election observation is important for ensuring that member states comply with its commitments. This is also affirms by the 1990 Copenhagen Document. It states; 'the participating States consider that the presence of observers, both foreign and domestic, can enhance the electoral process for States in which elections are taking place... Such observers will undertake not to interfere in the electoral proceedings'. ${ }^{13}$ It means that 'the OSCE participating states recognize election observation as a tool to promote and support free, fair and democratic elections' ${ }^{14}$

Several post-soviet counties did not take part in that meeting. For instance, the representative of Azerbaijan Republic did not participate in the adoption of Copenhagen document since Azerbaijan was not an independent state at the time. But, Azerbaijan Republic was participating state while adoption of Charter for European Security (1999) and Istanbul Summit Declaration (1999). Those documents also refer to 1990 Copenhagen Document. For example, Charter for European Security states "we reaffirm our obligation to conduct free and fair elections in accordance with OSCE commitments, in particular the Copenhagen Document 1990. We recognize the assistance the ODIHR can provide to

\footnotetext{
${ }^{11}$ See OSCE\ODHIR Final Report on 2000 Presidental Elections of Kyrgyz Republic. Available on http://www.osce.org/odihr/elections/kyrgyzstan/15802

${ }^{12}$ IDEA, Glossary of electoral terms. Available on: http://www.idea.int/publications/ies/upload/Annex $\% 204 . p d f$.

${ }^{13}$ Copenhagen Document, paragraph. 8. Available on: http://www.osce.org $/ \mathrm{mc} / 17502$ ?download=true.

${ }^{14}$ Christina Binder "International Election Observation by the OSCE and the Human Right to

Political Participation”, (2007), European Public Law, Vol 13, Issue 1, p.145.
} 
participating States in developing and implementing electoral legislation. In line with these commitments, we will invite observers to our elections from other participating States, the ODIHR, the OSCE Parliamentary Assembly and appropriate institutions and organizations that wish to observe our election proceedings. We agree to follow up promptly the ODIHR's election assessment and recommendations". ${ }^{15}$ Moreover, participants of Istanbul Summit recogize that they agreed comply with OSCE ODHIR's election commitments and recommendations. ${ }^{16}$ It means that Azerbaijan has obligated to comply with OSCE commitments.

In some countries, opposite parties and some Non-Governmental Organizations (NGOs) argue that proportional election system (or vice versia) is fair system. But 'neither human rights conventions nor OSCE commitments establish which election systems (majority, semi-proportional ot proportional representation) should be adopted or how it should be framed'. ${ }^{17}$ However, there are some suggestions by the OSCE on which system is suitable depending on social and democratic situation of the state. For example, During 2001 Parliamentary election Moldova had proportional representation (PR) system and in the Final Report of Moldova Parliamentary Elections, OSCE offered that state should reformed its electoral system with a view to assistanting the more effective participating of minorities in Parliament. ${ }^{18}$ Contrary to this recommendation, OSCE/ODHIR recommended that in forthcoming reforms Kazakhstan should take into account development of it's the political parties. ${ }^{19}$ There is not any offer or recommendation to Azerbaijan on reforms election system.

As above-mentioned there are some major elements (hold free elections at reasonable intervals (7.1), guarantee universal and equal suffrage (7.3)) and principles of elections in Copenhagen Document. All of those elements must be covered by domestic legislation of states.

\section{Instruments developed by the United Nations}

After established of the United Nations, human rights monitoring in particular election monitoring systems played decisive work in decolonization process. Thus

\footnotetext{
${ }^{15}$ Charter for European Security, 1999, paragraph 25.

${ }^{16}$ Istanbul Summit Declaration, 1999, paragraph 26.

${ }^{17}$ Christina Binder "International Election Observation by the OSCE and the Human Right to Political Participation", (2007), European Public Law, Vol 13, Issue 1, p.148.

${ }^{18}$ OSCE\ODHIR Final Report on 2001 Parliamentary Elections of the Republic of Moldova. 3 April 2001. Available on http://www.osce.org/odihr/elections/moldova/14837.

${ }^{19}$ OSCE ODHIR Review of the Election Legislation for Paliamentary Elections. 18 January 2001. Available on: http://www.osce.org/odihr/elections/kazakhstan/14799.
} 
after Second World War human rights documents created the legal basis for United Nations election monitoring system. United Nation competences and goals for monitoring the conduct of elections is indicated in its Charter. ${ }^{20}$

Several Conventions adopted by UN determined instruments on conduct of free and fair elections such as the 1948 Universal Declaration of Human Rights, the 1966 International Covenant on Civil and Political Rights. Moreover several convention recognized international standards for fair elections such as the Convention on the Elimination of all Forms of Discrimination against Women $(\mathrm{CEDAW}),{ }^{21}$ the Convention on the Political Rights of Women (CPRW), the International Convention on the Protection of the Rights of All Migrant Workers and Members of Their Families (MWC), ${ }^{22}$ International Convention on the Elimination of Racial Discrimination (ICERD), ${ }^{23}$ the Convention on the Rights of Persons with Disabilities (CRPD), and the General Recommendation $\mathrm{N}^{\circ} 23$ of the UN Human Rights Committee on Political and Public Life. Unlike OSCE standards, UN election standards have more wide scope and those legal binding on ratified states. But before above-mentioned Declaration, UN General Assembly adopted Resolution on the Problem of Independence of Korea. According to Resolution ( 112 (II) ) UN recommend that "Korean elections be held not later than 31 March 1948 on the basis of adult suffrage and by secret ballot to choose representative with whom the Commission may consult regarding the prompt attainment of the freedom and independence of the Korean People and ..... The number of representative from each voting area or zone should be proportionate to the population, and the elections should be under observation of the Commission". ${ }^{24}$ And the UN observed South Korean election in 1948 and this was first election monitoring of the UN.

The major principles of elections such as universal suffrage, secret vote, genuine and periodic elections found its first articulation in the UDHR. Especially Article 21 (3) of the UDHR says: "[the] will of the people shall be the basis of the authority of government; this will shall be expressed in periodic and genuine

\footnotetext{
20 "The basic objectives of the trusteeship system, in accordance with the Purposes of the United Nations laid down in Article 1 of the present Charter, shall be: to promote the political, economic, social, and educational advancement of the inhabitants of the trust territories, and their progressive development towards self-government or independence as may be appropriate to the particular circumstances of each territory and its peoples and the freely expressed wishes of the peoples concerned, and as may be provided by the terms of each trusteeship agreement".

${ }^{21}$ Especially art. 7.

${ }^{22}$ Especially art 41.

${ }^{23}$ Especially art. 5.

${ }^{24}$ Resolution of the UN General Assembly (112 (II)), 14 November 1947, Part B, paragraph 2. Available on: http://daccess-ddsny.un.org/doc/RESOLUTION/GEN/NR0/038/19/IMG/NR003819.pdf?OpenElement.
} 
elections which shall be by universal and equal suffrage and shall be held by secret vote or by equivalent free voting procedures". ${ }^{25}$ As we know, UDHR is not legally binding because it just "declaration" therefore it does not need ratification or accession. But in my view this UDHR especially article 21 (3) of its is a milestone standard for developing of international election standards.

The International Covenant on Civil and Political Rights has power among other documents. It has 165 States parties and Azerbaijan ratified it on 13 August 1992. Article 25 of ICCPR states "Every citizen shall have the right and the opportunity, without any of the distinctions mentioned in article 2 and without unreasonable restrictions: (a) To take part in the conduct of public affairs, directly or through freely chosen representatives; (b) To vote and to be elected at genuine periodic elections which shall be by universal and equal suffrage and shall be held by secret ballot, guaranteeing the free expression of the will of the electors; (c) To have access, on general terms of equality, to public service in his country". ${ }^{26}$ Article 25 of the International Covenant Civil and Political Rights covers main elements of the right to free and fair elections:

3 Genuine elections;

4 Universal suffrage;

5 Equal suffrage;

6 Periodic elections;

7 Secret ballot;

8 Freedom assembly;

9 Free expression;

There are some complicated terms such as genuine, periodic which are mentioned in UDHR as well. Periodic means that elections must be held at regular intervals. But what is mean genuine elections. 'Having connection with free election principle, genuine elections mean that eligible voters may freely choose among various alternatives - programmes, parties or at least several candidates of single party'. ${ }^{27}$

All of these elements are main requirements for conduct of free and fair elections and all of them have to be in component form so these components must be complied together. For example if during the election period all elements are complied, except freedom of speech or freedom of assembly, it could not be considered free and fair election. Because of election process does not just consist

\footnotetext{
${ }^{25}$ Universal Declaration of Human Rights 1948.

${ }^{26}$ ICCPR. Available on: http://www2.ohchr.org/english/law/ccpr.htm.

${ }^{27}$ Manfred Nowak, U.N. Covenant on Civil and Political Rights CCPR Commentary, Second edition, 2005. P. 575.
} 
of voting day. Violations of pre-elections, voting day and post elections influence the conduct of free and fair elections in all stages of election proceedings. It is also reflected in the definition of free and fair elections. The International Institute for Democracy and Electoral Assistance (IDEA) exlpained that free and fair elections "emanates from an electoral process which is a real contest where there is full enjoyment of fundamental freedoms and political rights related to elections: freedom of association, freedom of expression, freedom of movement and freedom of assembly". ${ }^{28}$

Essentially, the right to freedom of speech and freedom of assembly which noted in article 25 is a main principle of free elections. But according to the reports of international organizations, individuals' rights to freedom of speech and freedom of assembly are restricted by Constitution in some post-soviet states. Final Report of OSCE ODHIR on Early Presidental Elections of Kazakhstan says, "freedom of speech is guaranteed by the Constitution but effectively restricted by constitutional provisions protecting "honor and dignity", the continued criminalization of defamation and insult, and the higher protection afforded to the president and public officials". ${ }^{29}$ In the context of this Report, here is also breach of human rights conventions such as International Covenant on Civil and Political Rights.

ICCPR ensure universal suffrage right of people. But Article 25 could restrict or deny foriegners the right to vote. Because "the fact that Article is only provision in the Covenant that does not guarantee a universal human right". ${ }^{30}$ Also Azerbaijan Election Code imposed restrictions on the foreign citizens regarding participation in elections. Foreign citizens could participate in elections only on condition to live in appropriate territory for at least 5 years. But stateless persons could take part in all elections together with citizens if they lived at least 5 years in Azerbaijan. ${ }^{31}$ It is clear that such prohibition is important for the democratic society and it could not be considered violation of ICCPR. There are other special requirements in some countries' legislation. For example, in the case of Ignatane versus Latvia, "she claimed that be the victim of breach of Article 25 and 2 of ICCPR by Latvia because of she had not highest level of latvian language. And at result, "Human Rights Committee notes that article 25 secures to every citizen the right and the opportunity to be elected at genuine periodic elections without any of the

\footnotetext{
${ }^{28}$ Glossary of The International Institute for Democracy and Electoral Assistance (IDEA). Available on: http://www.idea.int/elections/ej/glossary.cfm.

${ }^{29}$ Final Report on 2011 Early Presidental Elections of the Republic of Kazakhstan, OSCE/ODHIR, 16 June 2011. Available on: http://www.osce.org/odihr/elections/78714.

${ }^{30}$ Manfred Nowak, U.N. Covenant on Civil and Political Rights CCPR Commentary, Second edition, 2005. P. 576.

${ }^{31}$ Aricle 12 of Election Code of the Republic of Azerbaijan.
} 
distinctions mentioned in article 2, including language". ${ }^{32}$ There is not such restriction in Azerbaijan legislation.

\section{Concluding remarks}

In order to conduct free and fair elections, above-mentioned international and regional election standards and protection mechanisms are essential. States should interpret its domestic laws and practice. It should be admitted that some of mentioned standarts do not possess legally binding power over states, however states can use these standarts as customary international provisions in thier legal practice.

\section{References and Notes:}

1. Christina Binder "International Election Observation by the OSCE and the Human Right to Political Participation", (2007), European Public Law, Vol 13, Issue 1, p.136160

2. Universal Declaration of Human Rights (UDHR) (1948).

3. The International Covenant on Civil and Political Rights (1966).

4. OSCE ODHIR, A decade of monitoring elections: the people and the practice; Available on; http://www.osce.org/odihr/elections/17165.

5. Document of the Cophenagen Meeting of the Conference on the Human Rights Dimension of the CSCE, 29 June 1990. Available on: http://www.osce.org/odihr/elections/14304.

6. 1990 Cophenagen Document (29 June 1990). Available on: http://www.osce.org/odihr/elections/14304.

7. OSCE/ODIHR Election Observation Mission Final Report on 2010 Parliamentary Elections of Azerbaijan (25 January 2011), page 4. Available on http://www.osce.org/odihr/elections/azerbaijan/75073.

8. OSCE\ODHIR Final Report on 2000 Presidental Elections of Kyrgyz Republic. Available on http://www.osce.org/odihr/elections/kyrgyzstan/15802

9. IDEA, Glossary of electoral terms. Available on: http://www.idea.int/publications/ies/upload/Annex\%204.pdf.

10. Manfred Nowak, U.N. Covenant on Civil and Political Rights CCPR Commentary, Second edition, 2005. P. 576.

11. Resolution of the UN General Assembly (112 (II)), 14 November 1947, Part B, paragraph 2. Available on: http://daccess-dds ny.un.org/doc/RESOLUTION/ GEN/NR0/038/19/IMG/NR003819.pdf?OpenElement

12. Antonina Ignatane v. Latvia, Human Rights Committee, 2001. Available on: http://www.unhcr.org/refworld/publisher.HRC..LVA.3f588ef83,0.html.

\footnotetext{
${ }^{32}$ Antonina Ignatane v. Latvia, Human Rights Committee, 2001. Available on: http://www.unhcr.org/refworld/publisher,HRC.,LVA,3f588ef83,0.html.
} 


\title{
Summary
}

\section{International free and fair election instruments developed by UN and OSCE}

\author{
Azer Kasumov \\ Riga Graduate School of Law, \\ Riga, Latvia
}

\begin{abstract}
After collapse of USSR, the international society confronted with a complicated challenge. After this, free and fair election standards became an essential component to establishing a democratic governments in the new independent states. In order to conduct free and fair election, the United Nations and the Organization for Security and Cooperation in Europe election standards played main role the respectively in the context of international and regional level. The Article briefly describes the importance and significance of main elements of free and fair elections. The author concluded that international election standards should be interpret its domestic laws and practice by states.
\end{abstract}

Key words: Collapse of USSR, United Nations, Organization for Security and Cooperation in Europe, free and fair election 